зображені події хоча й залишились у минулому, але підсвідомо вони продовжують впливати на людину. Фотографії допомагають пригадати минуле, усвідомити помилки, побачити образи.

13. Маскотерапія. Маска ліпиться на обличчі. Спочатку на шкіру наноситься крем, на який викладається перший шар паперу, а зверху приклеюється другий. Потім вона знімається й висушується, а далі розмальовується.

Отже, арт-терапія $\epsilon$ найбільш давньою та природною формою корекції емоційного стану, якою можна користуватись для зняття накопиченої психічної напруги, для того, щоб заспокоїтись чи просто зосередитись. Творчість як дитини, так і дорослого, реалізована у процесі арт-терапії, дає можливість висловити та відтворити внутрішні почуття, переживання, сумніви, конфлікти та сподівання, у символічній формі переживши ще раз важливі події, адже спонтанна образотворча діяльність здатна виражати неусвідомлюваний зміст психічного життя.

\title{
Література:
}

1. Киселева М. Арт-терапия в работе с детьми. Москва: Речь, 2014. $160 \mathrm{c}$.

2. Копытин А. Теория и практика арт-терапии. Санкт-Петербург: Питер, 2002. 368 c.

3. Никитин В. Арт-терапия. Москва: Когито-Центр, 2014. 336 с.

DOI https://doi.org/10.30525/978-9934-26-004-9-80

\section{КЛАРНЕТ У СИМФОНІЯХ ДМИТРА ШОСТАКОВИЧА В АСПЕКТІ ОСОБЛИВОСТЕЙ ОРКЕСТРОВОГО МИСЛЕННЯ}

\author{
Бойко П. А. \\ аспірант кафедри теорії та історії музичного виконавства \\ Науковий керівник: Качмарчик В. П. \\ доктор мистеитвознавства, професор \\ Національної музичної академії України імені П. І. Чайковського \\ м. Київ, Украӥна
}

Як відомо, Дмитро Шостакович - видатний композитор та симфоніст XX сторіччя, музикант трагічної долі. Складні обставини його мистецького життя були обумовлені тоталітарною епохою та моральною тиранією влади. Левон Акопян - дослідник творчості Д. Шостаковича 
відмічає неймовірну відповідність творчих настанов митця принципам гегелівської феноменології, тобто класичну «сукупність вияву абсолютного духу у свідомості, історії та мисленні» [1, с. 5]. Один із ракурсів видається для нас цінним, а саме: досвід митця, що нерідко стикався 3 «есхатологічними безоднями, прірвами», що спричинялись колізіями радянської історії, і цей факт прямо обумовлює особливості напряму еволюції творчості взагалі та впливає на принципи оркестрового мислення Д. Шостаковича зокрема.

Своєрідною межею для композитора, що перефарбовує свідомі та природні (базові) принципи оркестрового мислення, творчі погляди на роль кларнета для Дмитра Шостаковича, на наш погляд, слугує 1936 рік - рік страшних випробувань жорнами критики тоталітарної влади. Саме із Четвертої симфонії, написаної у цьому зловісному році, починаються зміни в принципах оркестрування симфонічної музики, які віддзеркалюють радикальний злам у виявленні творчої волі Д. Шостаковича.

Саме кларнет стає маркером творчої індивідуальності Шостаковича у ранній період творчості, коли були написані його перші три симфонії. У першій частині симфонії №1 тембр кларнета Шостаковичем задіяно доволі інтенсивно: у соло кларнета викладено усі основні теми твору. При зовнішній рихлості форми, мисленню композитора вже притаманна глибинна симфонізація, параметри якої відображені у партитурі симфонії не тільки в інтонаційно-тематичній єдності основних тем (що описано вже музикознавцями), але і в навмисній тембровій спорідненості тематизму в експозиційних та репризних розділах (на що нами звернено вперше). Тобто, в оркестровому мисленні, в аспекті тембровокомпозиційного задуму Першої симфонії Д. Шостаковичем саме партії кларнета відведено особливе місце: їй доручено не тільки експозиційне яскраве проведення тематизму (у відкритому solo кларнета в оркестрі), але й функція виявлення змістової єдності саме тембровою барвою кларнета у репризних розділах симфонії. Також присутня інша тенденція оркестрового мислення: Шостакович у партитурі Першій симфонії часто роз'єднує мелодико-тематичну лінію вступу, головної, побічної партій, інших тем на дрібні різнотемброві побудови - інструментальні мотиви або фігури, що йде всупереч вказаним традиціям інструментування Петербурзької школи - його Alma Mater.

Тембр кларнета в оркестрі був для молодого композитора самостійним носієм ідеї, фактором не тільки акустичної та функціонально-структурної рівноваги партитури твору, й аргументом ментальної єдності внутрішнього простору симфонії, рівноваги 
змістових тез та основою стрункої арки конструкції доволі індивідуального формотворення симфонії.

Симфонія № 2 сі-бемоль мажор, тв. 14, «Присвята Жовтню» (рос. «Октябрю») має на меті протилежні композиційні тенденції. Вона написана для великого симфонічного оркестру з хором у 1927 році. У першому фрагменті «Картина темного хаосу» кларнет не індивідуалізований, він є складовою навмисно створеної Шостаковичем «ультра-поліфонії» 327 одночасно звукових ліній різних оркестрових інструментів: «Вийшла ультра-поліфонія, що переходить у поліфонічний тембр» [2, с. 14]. Тобто, в оркестровому мисленні Д. Шостаковича з'являється поняття поліфонічний тембр, чим і продовжується розвиток тенденції в оркестровому мисленні композитора: тембр у Шостаковича взагалі $€$ самостійним параметром виразності, який має самоцінність навіть без його мелодійного або метроритмічного оформлення. Також помічаємо у трактуванні ролі кларнета прагнення залучити більш виразні видові інструменти сімейства кларнетових та прийоми гри міжтебрових барв у співставленні регістрів «кларіно» та «шалюмо». Так, кларнет in В у гротесково-гумористичних епізодах симфонії фактично використовує спектр виразності кларнета-пікколо (у особливостях регістра, штрихової техніки та засобів динамізації). Таким чином, у перших трьох симфоніях 20-х років Д. Щостакович апробовує усі можливості кларнетів, використовуючи два кларнета in A, in В у Першій симфонії, та по два кларнета in В у оркестрах Другої та Третьої симфонії.

Наступний етап у симфоніях $30-x$ років надає приклад радикальної творчої еволюції та більш широких можливостей усієї палітри сімейства кларнетових. 3 Четвертої симфонії Д. Шостакович значно розширює групу кларнетів в оркестрі, більш майстерно використовує кларнетпікколо, бас-кларнет, вводить дівізі кларнетів для забезпечення щільності звучання групи, що надає виразності тембровій грі, жвавості об'ємного акустичного простору звучання цієї групи. У І частині кларнет викладає тему головної партії у тутті, це - колективний монолітний образ. Перші дві частини симфонії пов'язані із участю кларнетів у колосальних розділах динамічного наростання. 3 третьої частини відбувається злам початкової стилістики симфонії, i, через трагічне трактування тембрів кларнета та бас-кларнета - втілення нових принципів мислення: ми маємо на увазі системне проведення мотивів траурного маршу у партіях сімейства кларнетових, i, взагалі, інтонаційну єдність кларнетового тематичного матеріалу. Увага до трагічного забарвлення концепції та переключення у шар монологічного висловлювання (особливо через сольні монологи кларнета) обумовлено особистими трагічними 
обставинами Д. Шостаковича. Цей фінал писався протягом лютого та весною 1936 року у досить складний та трагічний для Д. Шостаковича період сильної психологічної травми через навалу суворої критики та атаки влади на його видатний оперний твір - «Леді Макбет Мценського повіту». Саме 3 цього моменту у симфонічній музиці тематизм оркестрових партій виявляє щільну інтонаційну єдність всередині цілих партії навіть протягом різних частин твору. Цей аспект аргументує загальновідомий факт композиційного мислення композитора: Шостакович - симфоніст за природою обдарування, завжди незвичайно міцно вибудовував інтонаційну драматургію свого твору.

П'ята симфонія ре мінор, тв. 47, написана у 1937 році для потрійного складу симфонічного оркестру, з двома арфами, челестою та фортепіано. Особливістю оркестрового складу є відсутність бас-кларнета: в групі наявні два кларнети in A, in B, та кларнет-пікколо in Es. У партитурі П'ятої симфонії кларнет представлений переважно у складі цілісно потрактованої групи дерев'яних, майже відсутні його відкриті соло. Особливості оркестрового складу та драматургії симфонії надають підстави стверджувати, що тут декларовано новий тип оркестрового мислення, пов'язаний 3 підвищеною тембровою гомогенністю оркестрових груп та діалогу на рівні монолітних груп тембрів. Шостакович вже пройшов шлях від політембровой фактури ранніх симфоній, втілив принцип поліфонічного мислення тембрами, а не тільки інтонемами, і у П'ятій симфонії декларує принцип міжтембрового діалогу на рівні оркестрових груп. При переважанні поліфонічної фактури та наявності підголоскової поліфонії діалог стає тотальним i торкається як інтонаційного, так і міжтембрового шарів музики.

Шоста симфонія № 6 сі мінор, тв. 54 написана в 1939 році для потрійного складу симфонічного оркестру, у партитурі наявні чотири кларнети (третій дублюється кларнетом-пікколо, четвертий - дублюється бас-кларнетом). Кларнет тут інтерпретується у трьох напрямах: як невід'ємний представник монолітної групи дерев'яних (наприклад, у першій частині симфонії він не має відкритих соло); як транслятор риторичних мотивів семантизованого змістового шару (декламаційний мотив у розвиваючому розділі головної партії - бас-кларнет у дублюванні із фаготом; діалог між кларнетом та кларнетом-пікколо у розділі Sostenuto цифри 19, де ламентозний мотив декілька разів «перегукується» у діалозі сперечання з імперативним мотивом кларнетапікколо; двоголосся з мотивом на кшталт Dies irae у двох кларнетів), або у дусі скерцозних оркестрових творів Ф. Мендельсона (казково, таємничо, віртуозно, винахідливо). 
У симфоніях №№ 7 - 9 періоду сорокових років (відповідно, роки $1941,1943,1945)$ розгортається панорама оркестрових знахідок у галузі використання переважно виразних ресурсів бас-кларнета та кларнетапікколо.

3 симфоній 50-х років та початку шістдесятих (відповідно № $10-$ 1953 р., № 11 - 1957 р., № 12 - 1961 р.) стверджується новий тип розгорнутого оркестрового висловлювання композитора, а 3 ним i кларнетові соло починають змінюватися. Від активних учасників інструментального діалогу в оркестрі, група кларнетів переходить в нову якість носіїв розлогих відкритих соло монологічного типу, що й закріплюється у функціях кларнета у партитурах симфоній № 13 (1962 року) та № 15 - 1971 року.

\section{Література:}

1. Акопян Л.О. Дмитрий Шостакович: опыт феноменологии творчества. СПб.: изд-во «Дмитрий Буланин», 2004. 475 с.

2. Отчет аспиранта Ленинградской государственной консерватории Дмитрия Шостаковича: Архив ЛГК [без даты]. Шостакович Д. Д. Полное собрание сочинений в 42 томах. Том 01. М.: Музыка, 1987. С. 14.

DOI https://doi.org/10.30525/978-9934-26-004-9-81

\section{ПОПУЛЯРНА МУЗИЧНА КУЛЬТУРА УКРАЇНИ В ЕПОХУ ГЛОБАЛІЗАЦІЇ}

Борин О. В. аспірантка ДВНЗ «Прикарпатський наџіональний університет імені Василя Стефаника» м. Івано-Франківськ, Украӥна

Сучасна українська культура яскраво виражена розвитком популярної музичної культури. У період глобалізаційних процесів та соціокультурних змін з'являються нові культурні явища. Вивчення як позитивних, так і негативних впливів глобалізації на мистецькі процеси української національної культури займає важливе місце в сучасних культурологічних та мистецтвознавчих дослідженнях. 